\title{
Influenza-associated thrombotic microangiopathies
}

\author{
Martin Bitzan $^{1}$ (D) $\cdot$ Jakub Zieg $^{2}$
}

Received: 13 May 2017 /Revised: 11 July 2017 / Accepted: 8 August 2017 / Published online: 7 September 2017

(C) The Author(s) 2017. This article is an open access publication

\begin{abstract}
Thrombotic microangiopathy (TMA) refers to phenotypically similar disorders, including hemolytic uremic syndromes (HUS) and thrombotic thrombocytopenic purpura (TTP). This review explores the role of the influenza virus as trigger of HUS or TTP. We conducted a literature survey in PubMed and Google Scholar using HUS, TTP, TMA, and influenza as keywords, and extracted and analyzed reported epidemiological and clinical data. We identified 25 cases of influenza-associated TMA. Five additional cases were linked to influenza vaccination and analyzed separately. Influenza A was found in $83 \%, 10$ out of 25 during the 2009 A(H1N1) pandemic. Two patients had bona fide TTP with ADAMTS13 activity $<10 \%$. Median age was 15 years (range $0.5-68$ years), two thirds were male. Oligoanuria was documented in $81 \%$ and neurological involvement in $40 \%$ of patients. Serum C3 was reduced in 5 out of 14 patients (36\%); Coombs test was negative in 7 out of 7 and elevated fibrin/fibrinogen degradation products were documented in 6 out of 8 patients. Pathogenic complement gene mutations were found in 7 out of 8 patients tested (C3, MCP, or MCP combined with $\mathrm{CFB}$ or clusterin). Twenty out of 24 patients recovered completely, but
\end{abstract}

Electronic supplementary material The online version of this article (https://doi.org/10.1007/s00467-017-3783-4) contains supplementary material, which is available to authorized users

\section{Martin Bitzan}

martin.bitzan@mcgill.ca

Division of Nephrology, The Montreal Children's Hospital, McGill University Health Centre, 1001, boul. Décarie-Room B RC.6651, Montréal, QC H4A 3J1, Canada

2 Department of Pediatric Nephrology, 2nd Faculty of Medicine, University Hospital Motol, Charles University,

Prague, Czech Republic
3 died (12\%). Ten of the surviving patients underwent plasma exchange (PLEX) therapy, 5 plasma infusions. Influenzamediated HUS or TTP is rare. A sizable proportion of tested patients demonstrated mutations associated with alternative pathway of complement dysregulation that was uncovered by this infection. Further research is warranted targeting the roles of viral neuraminidase, enhanced virus-induced complement activation and/or ADAMTS13 antibodies, and rational treatment approaches.

Keywords Hemolytic uremic syndrome ·

Thrombotic-thrombocytopenic purpura $\cdot$ Complement . ADAMTS13 $\cdot$ Plasma exchange $\cdot$ Neuraminidase $\cdot$ Influenza vaccine

$\begin{array}{ll}\begin{array}{l}\text { Abbreviations } \\ \text { ADAMTS13 }\end{array} & \begin{array}{l}\text { A disintegrin-like metalloproteinase with } \\ \text { thrombospondin type 1 motif 13 }\end{array} \\ \text { aHUS } & \text { Atypical hemolytic uremic syndrome } \\ \text { AKI } & \text { Acute kidney disease } \\ \text { APC } & \text { Alternative pathway of complement } \\ \text { CFB } & \text { Complement factor B } \\ \text { CFH } & \text { Complement factor H } \\ \text { CFHR } & \text { Complement factor H-related protein } \\ \text { CFI } & \text { Complement factor I } \\ \text { CKD } & \text { Chronic kidney disease } \\ \text { CNS } & \text { Central nervous system } \\ \text { DCT } & \text { Direct Coombs test (direct agglutination test) } \\ \text { DD } & \text { Deceased (kidney) donor } \\ \text { DGKE } & \text { Diacylglycerol kinase-epsilon } \\ \text { ESRD } & \text { End-stage renal disease } \\ \text { FDP } & \text { Fibrin/fibrinogen degradation products } \\ \text { FP } & \text { Frozen plasma } \\ \text { HA } & \text { Hemagglutinin } \\ & \end{array}$




$\begin{array}{ll}\text { Hb } & \text { Hemoglobin } \\ \text { HD } & \text { Hemodialysis } \\ \text { HUS } & \text { Hemolytic uremic syndrome } \\ \text { iHUS } & \text { Influenza-associated HUS } \\ \text { IPD } & \text { Invasive pneumococcal disease } \\ \text { iTMA } & \text { Influenza-associated thrombotic } \\ & \text { microangiopathy } \\ \text { KT } & \text { Kidney transplant(ation) } \\ \text { LDH } & \text { Lactate dehydrogenase } \\ \text { MAC } & \text { Membrane attack complex (C5b-9) } \\ \text { MAHA } & \text { Microangiopathic hemolytic anemia } \\ \text { MCP } & \text { Membrane cofactor protein (CD46) } \\ \text { NA } & \text { Neuraminidase (influenza) } \\ \text { Nan } & \text { (Pneumococcal) neuraminidase } \\ \text { PD } & \text { Peritoneal dialysis } \\ \text { PI } & \text { Plasma infusion } \\ \text { PLEX } & \text { Plasma exchange } \\ \text { PLG } & \text { Plasminogen } \\ \text { Plt } & \text { Platelet(s) } \\ \text { pnHUS } & \text { Pneumococcal/neuraminidase HUS } \\ \text { PRBC } & \text { Packed red blood cells } \\ \text { sC5b-9 } & \text { Soluble (vitronectin-bound, plasmatic) mem- } \\ & \text { brane attack complex } \\ \text { STEC } & \text { Shiga toxin-producing Escherichia coli } \\ \text { TF Ag } & \text { Thomsen-Friedenreich antigen } \\ \text { THBD } & \text { Thrombomodulin (CD141) } \\ \text { TMA } & \text { Thrombotic microangiopathy } \\ \text { TTP } & \text { Thrombotic thrombocytopenic purpura } \\ \text { VWF } & \text { Von Willebrand factor } \\ & \end{array}$

\section{Introduction}

The term thrombotic microangiopathy (TMA) is used to describe a spectrum of phenotypically similar diseases characterized by intravascular (microangiopathic) hemolytic anemia (MAHA), thrombocytopenia, and in most instances, acute kidney injury (AKI). Other organ systems can be affected. Best-known examples are the hemolytic uremic syndromes (HUS) and thrombotic thrombocytopenic purpura (TTP). Although endothelial injury is a triggering event in many instances of HUS, this may not apply to the TTP and some forms of "atypical" HUS (aHUS).

Infections by Shiga toxin-producing Escherichia coli (STEC or Stx HUS) are the most common cause of TMA (HUS) in children. Less frequently, HUS has been linked to infections by other bacteria, such as Shigella dysenteriae type 1, Clostridium perfringens or Streptococcus pneumoniae, and by HIV, coxsackie-, Epstein-Barr (EBV), varicella or influenza viruses [1-3].

Thrombotic thrombocytopenic purpura, first described as a clinical entity by Moschcowitz in 1924, is now etiologically defined by the lack of plasmatic ADAMTS13 activity [4].
ADAMTS13, a metalloprotease secreted by megakaryocytes and endothelial cells, cleaves platelet-derived von Willebrand factor (VWF) "ultra large" multimers into smaller-molecular weight fragments $[4,5]$. Most TTP patients have circulating anti-VWF protease antibodies, often of the IgG4 class [6]. Inherited TTP, caused by mutations in the ADAMTS13 gene, is known as Upshaw-Shulman syndrome [5, 7].

Dysregulation of the alternative pathway of complement (APC) or the coagulation system due to genetic mutations or acquired antibodies, primarily to complement factor $\mathrm{H}(\mathrm{CFH})$, increases the risk of HUS, commonly referred to as "atypical" (aHUS) [2, 8]. Genes encoding components of the coagulation and fibrinolytic cascades etiologically linked to aHUS are THBD (thrombomodulin), DGKE (diacylglycerol kinase-epsilon), VWF (von Willebrand factor), factor XII, and PLG (plasminogen) [8-12]. Other forms of "atypical" HUS (aHUS) are caused by abnormalities in the cblC pathway (methylmalonic aciduria and homocystinuria, cblC complementation type [MMACHC]) [13]. Finally, TMA may develop because of immunosuppressive and cytotoxic drugs, bone marrow transplantation, autoimmune diseases, cancer, and pregnancy. Although complement gene mutations have been identified in some of the latter conditions, the etiology is speculative in others $[1,2,8]$.

This review summarizes current evidence on the link between influenza virus infection and TMA (HUS or TTP) and discusses the overlap between influenza TMA and other forms of aHUS, in addition to the diagnostic workup and management of these conditions.

\section{Identification of cases of influenza TMA}

Using PubMed and Google Scholar, the following key words were used alone or in combination: hemolytic uremic syndrome, thrombotic thrombocytopenic purpura, thrombotic microangiopathy, influenza, influenza vaccine/vaccination. Clinical, epidemiological, and demographic features, laboratory results, treatment modalities and outcome were extracted and tabulated. English, French, and German language publications were reviewed.

\section{Influenza epidemiology and mechanisms of infection}

Influenza viruses can cause seasonal infections and epidemics with significant morbidity and mortality. The influenza A(H1N1) pandemic in 1918-1919 was responsible for the death of an estimated 50 million people [14]. The 2009 influenza pandemic by a newly arisen influenza $\mathrm{A}(\mathrm{H} 1 \mathrm{~N} 1)$ strain caused the death of more than 280,000 persons worldwide ( $>12,000$ in the USA) within the first year of its circulation, owing to respiratory or cardiovascular complications [15]. 
Seasonal influenza leads to an estimated $12,000-56,000$ deaths in the USA annually [16].

Influenza virus targets the respiratory tract and causes fever, often with acute laryngitis, tracheitis, and pneumonia, and occasionally myocarditis, meningoencephalitis, or rhabdomyolysis, among other symptoms [17]. Infants and the elderly are at greatest risk of influenza-related complications. Death may occur directly by the virus or by complicating bacterial pneumonia, especially due to $S$. pneumoniae. Influenza virus belongs to the genus Orthomyxovirus of the Orthomyxoviridae family. Influenza A and B viruses contain eight antisense strand RNA segments and express at least 17 proteins, among them three membrane (glyco)proteins in the lipid envelope: hemagglutinin (HA), neuraminidase (NA), and proton channel matrix protein 2 (M2) [17]. HA and NA are genetically unstable and determine fluctuations of the prevalent subtypes of influenza virus. Viral HA mediates attachment to sialic acid-containing host cell membrane receptors and entry of the viral genome into the target cells. Human influenza strains bind terminal $\alpha 2,6$ galactose residues, which contributes to the known species tropism $[17,18]$. Sialic acid-independent attachment has been postulated [19]. Viral neuraminidase cleaves $\alpha$-ketosidic bonds of neuraminic acid [20]. It facilitates transfer of virus particles in the mucus layer of the respiratory tract and release of progeny virion from infected cells $[17,21]$. NA inhibitors, such as oseltamivir (active metabolite oseltamivir carboxylate), block the release of virions and their spread to neighboring epithelial cells [21].

\section{Influenza-associated thrombotic microangiopathy}

Hemolytic uremic syndrome triggered by influenza virus (iHUS) is rare. In almost all instances, it is associated with influenza A virus, mainly $\mathrm{A}(\mathrm{H} 3 \mathrm{~N} 2)$ and $\mathrm{A}(\mathrm{H} 1 \mathrm{~N} 1)$. Only recently have a few cases of HUS associated with influenza B virus infection been published (Table 1) [22, 23]. Ten patients with HUS were noted during the 2009 influenza A(H1N1) pandemic [26-35], and one during a later wave [36], constituting $44 \%$ of all reported occurrences of influenza-associated thrombotic microangiopathy (iTMA; Tables 1,2). The distribution of these cases corresponded to the course of the pandemic [44] and differed from the usual seasonal influenza pattern (Fig. 1).

The first description of iHUS from 1971 is that of a 20-yearold kidney transplant recipient (\#1) [37]. The patient was diagnosed with MAHA and graft failure 1-2 weeks after the onset of influenza, almost 2 years after renal transplantation. End stage renal disease (ESRD) was secondary to acute proliferative glomerulonephritis (GN) and malignant hypertension. She started hemodialysis 10 days before transplant nephrectomy. Additional acute laboratory features were cold agglutinins (with negative direct Coombs test) and transiently reduced plasma $\mathrm{C} 3$
Table 1 Distribution of influenza virus subtypes associated with thrombotic microangiopathies in humans

\begin{tabular}{llll}
\hline Influenza types $^{\text {a }}$ & Influenza A & Influenza B & References \\
\hline A(H3N2) & 2 & & {$[24,25]$} \\
A(H1N1) & 11 & & {$[26-36]$} \\
A (not or partially specified) & 7 & 4 & {$[37-42]$} \\
B (Yamagata) & & 4 & {$[22,23]$} \\
\hline
\end{tabular}

${ }^{\text {a }}$ Viral typing was omitted in one reported case [43]

concentration. A graft biopsy 5 weeks after HUS onset revealed thrombosis of small renal arteries and glomerular capillaries. The transplant was removed 8 weeks after HUS onset, followed by swift normalization of the hematological parameters. A subsequent graft from a deceased donor (DD) was tolerated well without recurrence of HUS.

A typical scenario of HUS due to influenza $\mathrm{A}(\mathrm{H} 1 \mathrm{~N} 1)$ infection is a previously healthy, 7-year-old boy with febrile pneumonitis and transient respiratory failure who developed severe AKI, profound MAHA, and thrombocytopenia associated with hypertensive encephalopathy 5 days after the onset of respiratory symptoms (\#11). Coagulation profile, plasma fibrinogen, Coombs test, and $\mathrm{C} 3$ concentration were normal, as was MCP expression, plasma ADAMTS13 activity and serum CFB, CFH and CFI concentrations. He recovered completely after 2 weeks of peritoneal dialysis. No genetic studies of APC or coagulation factors were reported by the authors [28].

Relevant demographic, clinical and laboratory parameters of all patients identified with influenza A- and B-associated TMA are summarized in Table 2 (for details, see Supplementary Table S1). Three of the influenza A HUS patients had a kidney transplant at the time of infection, including \#1. Patient \#5 had been transplanted for chronic GN; allograft biopsy on day 10 of HUS revealed mesangiolysis and $\mathrm{C} 3$ deposition in the presence of normal serum $\mathrm{C} 3$ concentrations. Patient \#16 had lost two previous allografts due to HUS caused by an activating $\mathrm{C} 3$ mutation [33].

Patients presented with hemolytic anemia that was associated with peripheral schistocytosis in all but one instance [33], and thrombocytopenia (nadir 5-80 $\times 10^{9}$ platelets/L). Peripheral platelet counts recovered after a median of 9.5 days (range 6-23 days; $n=8$ patients; Table 2). Direct and indirect Coombs tests were negative in all 7 patients examined, but cold agglutinins were reported once (\#1) [37]. Six of 8 patients (75\%) tested for evidence for fibrinolysis showed elevated ddimers and fibrin/fibrinogen degradation products (FDP), with normal fibrinogen levels (Table 2) [29, 32, 36, 38, 39].

Acute kidney injury (AKI) developed in all 25 patients. Hypertension was present in 10 out of 23 patients $(43 \%)$. Serum creatinine concentrations were already increased at first measurement in 19 out of 21 patients $(90 \%$; median $221 \mu \mathrm{M}$ 


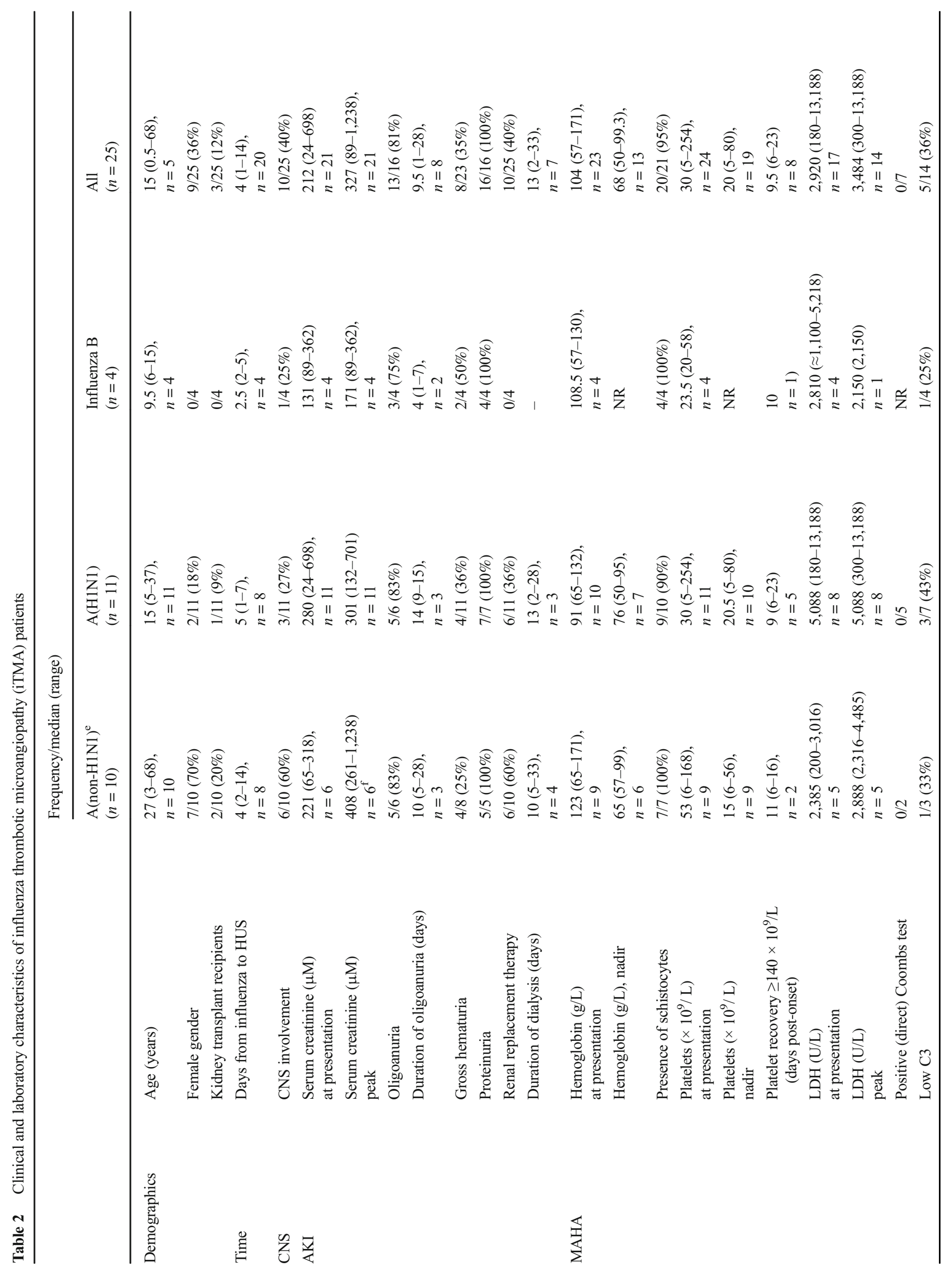




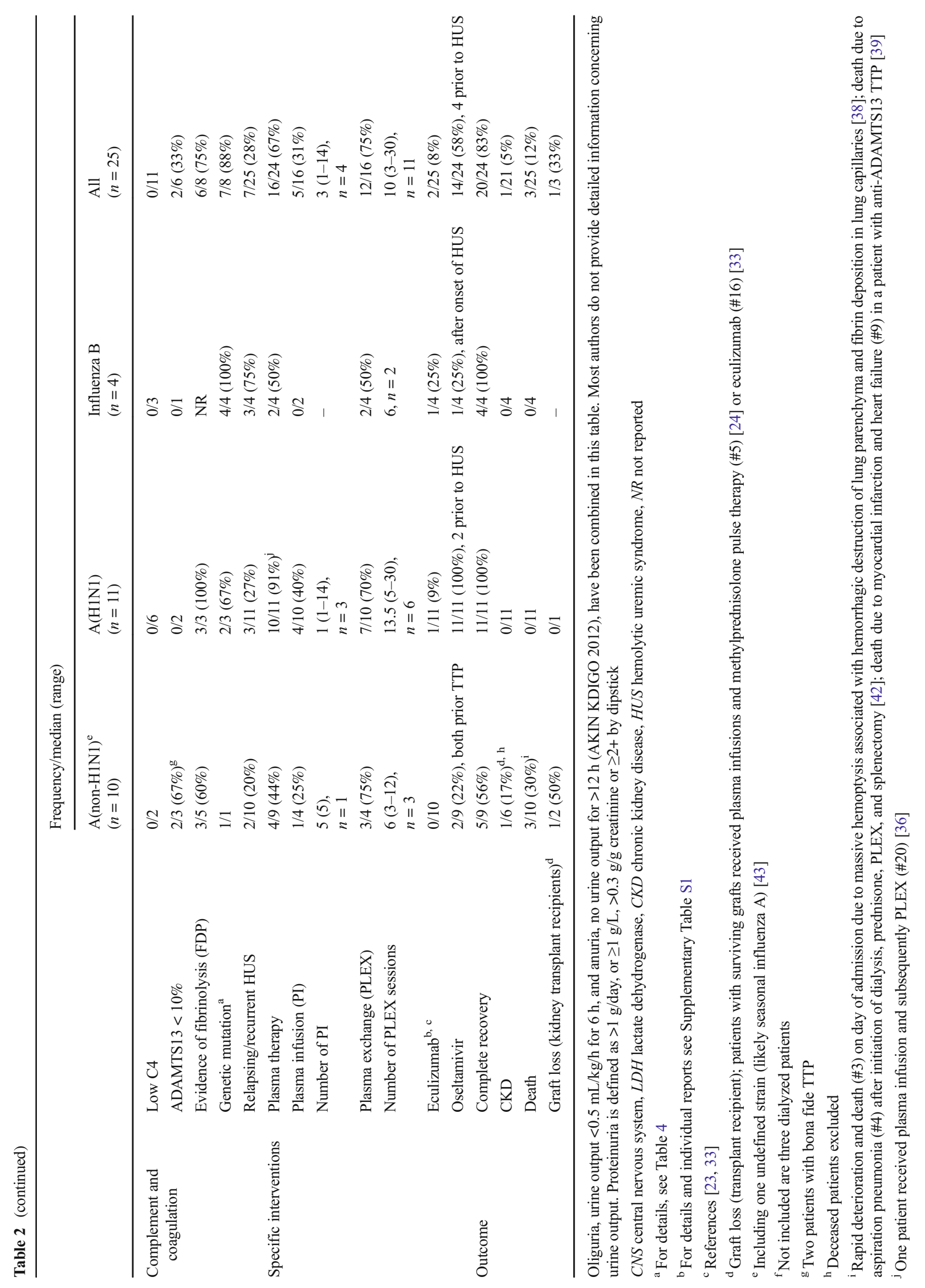




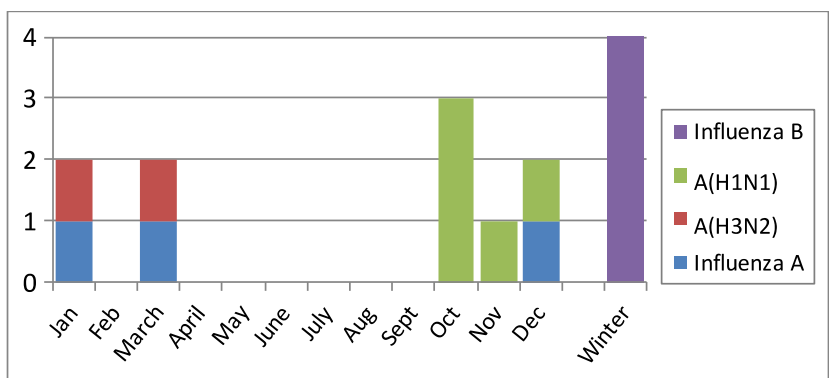

Fig. 1 Seasonal distribution and influenza subtypes in patients with influenza-associated thrombotic microangiopathy (TMA). The occurrence of $\mathrm{A}(\mathrm{H} 1 \mathrm{~N} 1)$-linked hemolytic uremic syndrome (HUS) coincides with the peak of the 2009 pandemic (weeks 40-51). In contrast, the expected peak of seasonal influenza $\mathrm{A}$ is during the first 3 months of the year [44]

[2.4 mg/dL]) and peaked at $327 \mu \mathrm{M}(3.7 \mathrm{mg} / \mathrm{dL})$. Oliguria or anuria was documented in 13 out of 16 cases $(81 \%)$. Ten patients $(40 \%)$ initiated renal replacement therapy, mostly in the form of hemodialysis (median duration 13 days; Table 2). Kidney biopsies were reported in 7 patients $(\# 1-6,16)$. An example of pertinent histopathological features of influenza A-associated HUS is shown in Fig. 2.

Central nervous system (CNS) complications, including drowsiness and mental confusion, focal neurological signs, seizures, and hemiplegia, in addition to Magnetic resonance imaging (MRI) changes and petechiae (in brain autopsy samples; Table S1) were reported in 10 iHUS patients (40\%). The severity and frequency of CNS complications associated with $\mathrm{A}(\mathrm{H} 1 \mathrm{~N} 1)$ versus $\mathrm{A}($ non-H1N1) influenza did not reach statistical significance ( $p=0.20$; Fisher's exact; Table 2).

Separate analysis of the reported A(H1N1) HUS cases revealed evidence for variable abnormalities of complement and fibrinolysis, similar to the remainder of influenza A HUS cases (Table 2). It remains unclear if $\mathrm{A}(\mathrm{H} 1 \mathrm{~N} 1)$ has a greater propensity to induce HUS than other influenza subtypes [45]. Considering that there is a total disease burden of 200 million people globally [46], the proportion of (reported) HUS cases is about 0.05 per 1 million influenza $\mathrm{A}(\mathrm{H} 1 \mathrm{~N} 1)$ infections, this corresponds to two cases (\# 5 and 16) among 50 million patients reported in the USA [46, 47].

The reported clinical and laboratory features of the children with influenza B-associated HUS $[22,23]$ resemble those described for influenza A. Interestingly, HUS was linked in all instances to genetic complement abnormalities (see below and Table 2).

\section{Influenza and TTP}

Influenza A virus, including $\mathrm{A}(\mathrm{H} 1 \mathrm{~N} 1)$ has been invoked as a cause of TTP in at least four published reports [34, 35, 39, 40]. ADAMTS13 activity was depleted in 2 patients; both demonstrated increased anti-ADAMTS13 antibody concentrations [39, 40]. The TTP diagnosis of the remaining 2 patients was clinical, based on the combination of MAHA and neurological manifestations, while ADAMTS13 and complement studies were lacking (Table 3) [34, 35]. The mechanism leading to the rise of antiADAMTS13 and other autoantibodies by influenza and influenza vaccines $[48,49]$ warrants additional research.

\section{Pathogenesis of iHUS}

There is an established link between influenza virus infection and HUS, but the underlying mechanism is speculative [45]. Influenza virus shares with $S$. pneumoniae the ability to produce neuraminidase. However, in vivo NA shedding by influenza virus is minimal (it is expressed on the viral membrane) compared with $S$. pneumonia $[18,50]$. Its contribution to the pathogenesis of HUS has still to be shown.

Autopsy studies during the $2009 \mathrm{~A}(\mathrm{H} 1 \mathrm{~N} 1)$ pandemic revealed viral antigen in endothelial cells [51]. In vitro infection of endothelial cells by influenza virus [52] can trigger apoptosis [53], a process known to stimulate platelet adhesion directly and via the exposure of extracellular matrix $[54,55]$. In

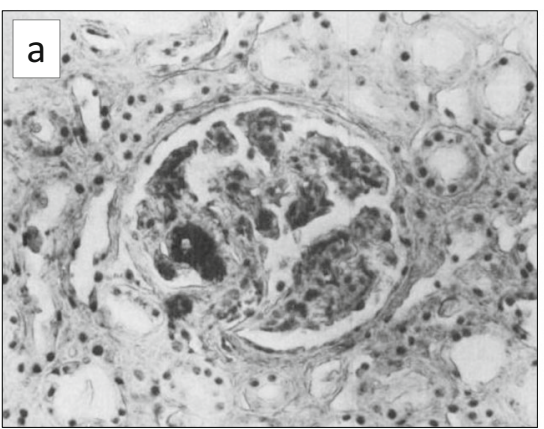

Fig. 2 Micrographs from a patient with influenza thrombotic microangiopathy in the kidney allograft (patient \#1). a Glomerulus with thrombosis of a capillary loop (phosphotungstic acid hematoxylin stain). b Cross-section of arteriole: the wall shows splitting and edema; the lumen is occluded by a thrombus (hematoxylin-eosin stain). Thrombi

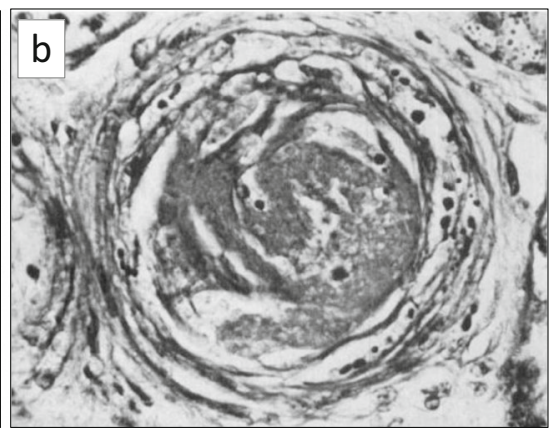

consisted of fibrin in addition to packed erythrocytes and thrombocytes. Some thrombi merged with the arteriolar wall, which then showed fibrinoid necrosis (reproduced from Petersen and Olsen [37], used with permission) 
Table 3 Demographic and clinical details of influenza-associated HUS and TTP

\begin{tabular}{|c|c|c|c|c|}
\hline \multirow[t]{2}{*}{ Features } & & \multicolumn{2}{|l|}{ HUS } & \multirow{2}{*}{$\begin{array}{l}\text { TTP } \\
\text { ADAMTS } 13<10 \% \\
n=2\end{array}$} \\
\hline & & $\begin{array}{l}\text { Undefined HUS } \\
n=15\end{array}$ & $\begin{array}{l}\text { Genetic complement } \\
\text { dysregulation }^{\mathrm{c}} \\
n=8\end{array}$ & \\
\hline \multirow[t]{2}{*}{ Demographics } & Female gender & $5 / 15(33 \%)$ & $2 / 8(25 \%)$ & $2 / 2(100 \%)$ \\
\hline & Age at presentation (years) & $14(3-50)$ & $15(0.5-35)$ & $57.5(47-68)$ \\
\hline \multirow[t]{4}{*}{ Influenza type } & A (non-H1N1) & 7 & - & 2 \\
\hline & $\mathrm{A}(\mathrm{H} 1 \mathrm{~N} 1)$ & 8 & 3 & - \\
\hline & $\mathrm{B}$ & - & 4 & - \\
\hline & Undefined type & - & 1 & - \\
\hline Renal status & Kidney transplant & $2 / 15(13 \%)$ & $1 / 8(13 \%)$ & $0 / 2$ \\
\hline \multirow[t]{2}{*}{ Clinical aspects } & CNS symptoms & $8 / 15(53 \%)$ & $1 / 8(13 \%)$ & $1 / 2(50 \%)$ \\
\hline & Macrohematuria & $6 / 14(43 \%)$ & $2 / 7(29 \%)$ & $0 / 2$ \\
\hline \multirow[t]{4}{*}{ Biological parameters ${ }^{\mathrm{a}}$} & Creatinine $(\mu \mathrm{M})$ & $327(132-1,238), n=11$ & $309(89-543), n=8$ & $462(261 ; 650)$ \\
\hline & Platelets (nadir) & $21(5-85), n=14$ & $25(8-80), n=8$ & $6(6 ; 6), n=2$ \\
\hline & Hemoglobin & $77(50-105), n=14$ & $92(57-130), n=7$ & $108(66 ; 150), n=2$ \\
\hline & LDH (U/L) & $4,142(847 \geq 6,000), n=8$ & $2,810(300-13,188), n=8$ & $2,100(200 ; 4,200), n=2$ \\
\hline \multirow{3}{*}{$\begin{array}{l}\text { Complement and } \\
\text { coagulation }\end{array}$} & C3 low & $2 / 8(25 \%)$ & $3 / 7(43 \%)$ & NR \\
\hline & ADAMTS $13<10 \%$ & $0 / 2$ & $0 / 2$ & $2 / 2(100 \%)$ \\
\hline & FDP & $5 / 7(71 \%)$ & NR & $1 / 1$ \\
\hline \multirow[t]{4}{*}{ Therapy } & RRT (dialysis) & $8 / 15(53 \%)$ & $1 / 8(13 \%)$ & $1 / 2(50 \%)$ \\
\hline & Plasma infusion & $5 / 9(44 \%)^{\mathrm{b}}$ & $1 / 7(14 \%)$ & $0 / 2$ \\
\hline & PLEX & $6 / 9(67 \%)^{b}$ & $4 / 7(57 \%)$ & $2 / 2(100 \%)$ \\
\hline & $\begin{array}{l}\text { Anti-complement } \\
\text { (eculizumab) }\end{array}$ & $0 / 15$ & $2 / 8(25 \%)$ & $0 / 2$ \\
\hline
\end{tabular}

$F D P$ fibrin degradation products, $L D H$ lactate dehydrogenase, $P L E X$ plasma exchange, $R R T$ renal replacement therapy

${ }^{a}$ Peak or nadir (or highest/lowest reported measurement)

${ }^{\mathrm{b}}$ One patient was first treated with plasma infusion, followed by PLEX

${ }^{\mathrm{c}}$ Seven patients with at least one pathogenic mutation (see Table 4); one patient (\#13) with presumed membrane cofactor protein mutation (only tested for $\mathrm{CFH}$, CFHR1, and anti-CFH antibodies)

addition to injuring or activating vascular endothelial cells, influenza virus may directly affect platelets. A(H3N2) virus induces clumping of human and rabbit platelets in vitro, and a rapid drop of platelet counts in vivo after injection of the virus into rabbits [56]. More recent studies have confirmed the potential of influenza virus to activate platelets and generate thrombin $[57,58]$. In a prospective study comparing patients with acute respiratory distress syndrome (ARDS) due to severe influenza $\mathrm{A}(\mathrm{H} 1 \mathrm{~N} 1)$ and bacterial pneumonia with healthy controls, influenza showed the greatest degree of platelet activation measured as the formation of platelet-monocyte aggregates and activation of $\alpha \mathrm{Ilb} \beta 3$ integrin on platelets [57].

\section{Influenza virus and complement}

Complement regulates influenza virus-induced inflammation in the lung, enhances viral clearance, and protects against severe influenza infection [59]. Considered an important upstream mediator of the innate immune system, complement also bridges innate and adaptive immunity and is tightly linked to the coagulation cascade [60,61]. More than 50 known complement proteins are expressed by hepatocytes, but also by tissue macrophages, blood monocytes, and renal and gastrointestinal epithelial cells [62]. Complement can be activated via three recognized pathways: alternative, classical, and mannan-binding lectin pathways, all resulting in the enzymatic cleavage of $\mathrm{C} 5$, the formation of the membrane attack complex (MAC) and of potent chemokines [61, 62]. It exerts both protective and potentially deleterious effects: it protects through virus neutralization via direct aggregation, opsonization, lysis, and promotion of phagocytosis involving complement receptors, and indirectly enhances T- and B-cell responses [61]. Complement also contributes to influenza-associated respiratory tissue injury, e.g., due to the generation of potent proinflammatory peptides $[63,64]$. Neutralization of influenza virus in serum is mediated by the classical complement pathway via virusreactive IgM [65]. Complement, complement receptors, and 
natural IgM antibodies appear to contribute to the maintenance of long-term memory of the influenza virus. However, influenza virus particles can activate complement in the absence of antibody [64].

Viral activation of the APC in the respiratory tract leads to ciliary dysfunction in vitro and increased levels of $\mathrm{C} 3 \mathrm{a}$ and $\mathrm{C} 5 \mathrm{a}$ in bronchial lavage fluid and serum of patients with severe influenza [66, 67]. Complement C5 activation during influenza A virus infection contributes to neutrophil recruitment and lung injury in mice [20]. Berdal et al. reported a $>10$-fold increase in plasmatic levels of soluble MAC (sC5b-9) in patients with severe influenza by the pandemic $\mathrm{A}(\mathrm{H} 1 \mathrm{~N} 1)$ strain, indicating systemic complement activation [68].

Influenza-associated acute lung injury (ALI) in $\mathrm{A}(\mathrm{H} 5 \mathrm{~N} 1)$ infected mice has been linked to excessive complement activation with deposition of $\mathrm{C} 3$ and $\mathrm{C} 5 \mathrm{~b}-9$, and increased expression of complement receptors $\mathrm{C} 3 \mathrm{aR}$ and $\mathrm{C} 5 \mathrm{aR}$. Treatment with a $\mathrm{C} 3 \mathrm{aR}$ antagonist alleviated pulmonary inflammation in this model [69]. In another study, prevention of C5a release dampened inflammatory reactions caused by severe influenza A virus infection [63]. Treatment with anti-C5 antibody or C5a blockers inhibited influenza A virus-induced granulocyte activation and ALI. However, $\mathrm{C} 3$ and lytic MAC formation was protective in controlling murine influenza A virus infection [59]. The study confirmed earlier results showing delayed influenza virus clearance from the upper respiratory tract, reduced T-cell priming, and viral spreading to the lungs in C3deficient mice [70].

\section{Complement abnormalities associated with iHUS}

In our literature survey, plasma $\mathrm{C} 3$ levels were reported in 14 patients with iHUS; they were reduced in $5(36 \%)$ and $\mathrm{C} 4$ was normal in 11 cases (Table 2). Eight patients, 4 with influenza $A$ and 4 with influenza B infection respectively, underwent genetic screening. Seven were found to have AP component defects, including 3 patients with previous HUS episodes and a teenager with a renal allograft (Table 4). The latter patient carried a C3 gain-of-function mutation and had lost two previous kidney transplants owing to HUS recurrences; he was successfully treated with eculizumab for influenza-triggered HUS [33]. In addition, a 15-year-old girl (\#13) was reported to have a suspected MCP mutation (based on the history of frequently relapsing aHUS that resolved spontaneously). The genetic workup was incomplete and showed normal $\mathrm{C} 3$ and $\mathrm{C} 4$, factor $\mathrm{H}$, and factor I levels, undetectable $\mathrm{CFH}$ antibody, and lack of $\mathrm{CHF}$ mutation or CFHR1 deletion (Aysun Çaltik, personal communication). Interestingly, all four children with influenza B-associated HUS, published in 2017, carried one or more mutations of complement-related proteins [22, 23]. Although the number of genetically tested iTMA patients is small, we noted a high representation of $\mathrm{C} 3$ ( 3 out of 7) and MCP mutations (4 out of 7), combined with mutations of the clusterin and CFB genes respectively (Table 4).

Ten of the 25 reported patients with influenza-related TMA in our survey $(40 \%)$ were involved in the $2009 \mathrm{~A}(\mathrm{H} 1 \mathrm{~N} 1)$ pandemic (Table 1). Some authors raised the question of whether the pandemic $\mathrm{A}(\mathrm{H} 1 \mathrm{~N} 1)$ strain poses an increased HUS risk [45]. This hypothesis is interesting in light of the case series by Berdal et al., who noted evidence for vigorous complement activation (and a tenfold increase in MAC levels in plasma) in patients with severe (complicated) influenza infection (none had HUS) [68].

We postulate that infections by microbial agents with potent complement-activating capacities, including certain influenza virus strains, confer an enhanced risk of inducing HUS in patients with APC regulator protein haplo-insufficiency. Data from various laboratories suggest a complex interplay between environmental factors (such as highly-active complement-activating biological agents) and risk haplotypes (combined mutations or risk polymorphisms) [1,71], which may contribute to the variable, incomplete penetrance of genetic forms of aHUS.

\section{TMA following influenza vaccination}

Thrombotic microangiopathy has been linked to influenza vaccines in a few adults since at least 1973 (median age 51 years, range $23-56$ years). Analysis of five accessible reports showed a median interval of 2 weeks ( 4 days to 3 months) between immunization and onset of HUS $(n=2)$ and (presumed) TTP (associated with depleted ADAMTS13 activity and/or increased anti-ADAMTS13 antibodies; $n=3$ ) [43, 72-75]. Direct and indirect Coombs tests were negative in 3 out of 3 patients, and 1 out of 2 patients demonstrated increased FDP levels. One patient tested negative for antiCFH antibodies (\#4), but no other complement studies were performed or reported (see Table 6). Disease manifestations and severity were highly variable: HUS cases (\#1 and \#5) were relatively mild, and both patients recovered with supportive treatment, with or without added prednisone [43, 72]. In contrast, TTP patients underwent prolonged PLEX, rituximab (\#3 and 4) [74, 75], or vincristine treatment and splenectomy (\#2) [73].

The pathomechanism linking TMA with influenza vaccines is poorly understood. The clinical phenotype and spectrum or TMA (HUS, TTP) following natural influenza infections and post-vaccination are comparable. However, none of the 5 patients required renal replacement therapy. As with iHUS and idiopathic TTP (iTTP), complement studies and screens for APC and related gene mutations are necessary for a rational treatment strategy. Similar to natural infections, flu vaccines may induce anti-ADAMTS13 antibodies [48] and activate 


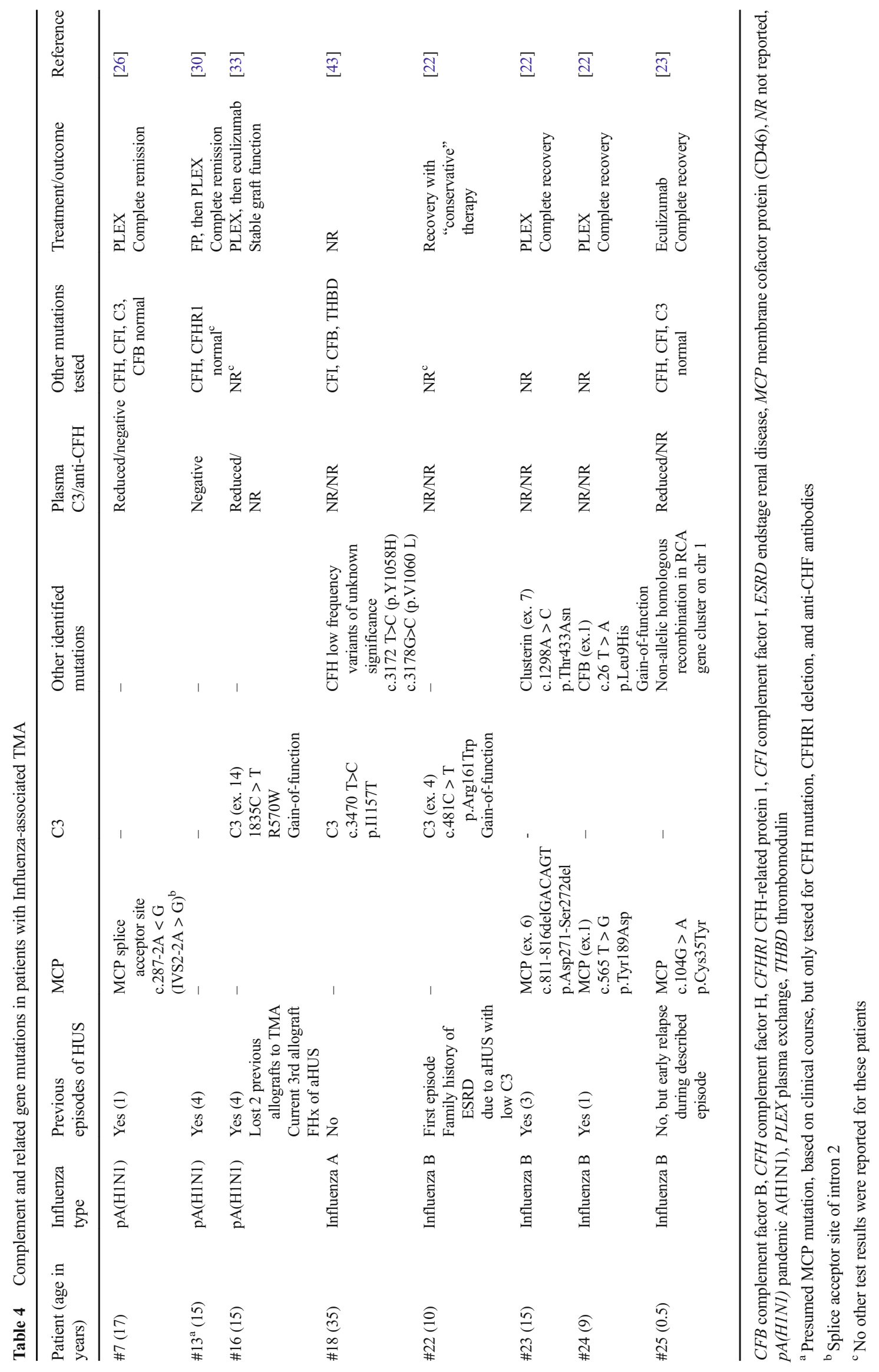


complement directly and cause HUS in patients with certain risk haplotypes [71].

\section{Neuraminidase and the link between influenza and Streptococcus pneumoniae infections}

Streptococcus pneumoniae, a Gram-positive, $\alpha$-hemolytic, facultative anaerobic bacterium commonly colonizes the human nasopharynx. Commensal strains form biofilms without causing disease [76]. Pathogenic strains are responsible for invasive pneumococcal disease (IPD), including pneumonia, otitis media, meningitis, and peritonitis arising from the respiratory tract $[77,78]$.

Influenza virus is known to increase host susceptibility to (severe) S. pneumonia infection [79]. There is bi-directional interaction between these two pathogens [45, 79]. Neuraminidase (Nan) is an important virulence factor of pathogenic pneumococcal strains, supporting colonization and sepsis in vivo [80]. Ubiquitous NanA hydrolyzes $\alpha 2,3-$, $\alpha 2,6-$, and $\alpha 2,8$-sialyllactose to release $N$-acetyl-neuraminic acid (Neu5Ac) [50]. Viral and pneumococcal NAs possess distinct quaternary structures, but their active sites are similar and susceptible to neuraminidase inhibitors (NAIs), such as oseltamivir [81, 82].

The risk of pneumococcal pneumonia rises transiently by an estimated 100-fold following influenza [79, 83]. Importantly, IPD has also been associated with HUS (pneumococcal or pnHUS), mostly with pneumonia/pleural empyema or (pneumococcal) meningitis [78, 84].

HUS caused by $S$. pneumoniae infection was first described by Fischer et al. in 1971 [85]. It predominantly affects children $<2$ years of age and constitutes up to $5 \%$ of all pediatric cases of HUS [86]. S. pneumoniae-derived circulating Nan cleaves membrane sialic acid residues, unmasking a core disaccharide structure, Gal $\beta 1-3$ GalNAc $\alpha 1$, known as Thomsen-Friedenreich (TF) antigen, on red blood cells, platelets, and glomerular endothelial cells. One hypothesis states that preformed IgM binds to TF antigen and induces a cascade of events leading to HUS [77]. Alternatively, desialylation of membrane proteins may interfere with CFH binding and regulatory function, resulting in transiently unregulated APC activation as a cause of HUS. A recent study by Szilágyi et al. demonstrated signs of complement activation in all five described patients with pnHUS; three of them carried pathogenic mutations and potential risk haplotypes [87].

pnHUS patients are commonly Coombs test-positive, a feature that has been related to Nan-mediated desialylation $[3,84,85]$. By comparison, the direct Coombs test was negative in 7 of the examined iHUS patients (Table 2). Cold agglutinins were noted in a single case (\#1; Table S1) [37], but their significance is unclear. Influenza virus produces quantitatively less NA than pneumococci. Viral NA is membrane-associated $[18,81]$, but may suffice to transiently disturb APC control. Of note, influenza virus-mediated desialylation of cell membrane glycans has been linked to vigorous $\mathrm{C} 3 \mathrm{~b}$ deposition and alternative pathway activation [88].

Influenza NA catalyzes cleavage of terminal sialic acid residues on epithelial membrane glycoproteins and glycolipids, providing mucin as a carbon source for rapidly increasing pneumococci leading to enhanced bacterial loads and severe infection/pneumonia [79, 89]. Similar metabiotic mechanisms have been postulated for influenza virus, and $H$. influenzae and S. aureus respectively, in addition to NAproducing parainfluenza virus [90]. We identified one case of influenza A iHUS that was complicated by $S$. pneumoniae infection and associated with unmasking of the TF antigen (case \#8, Table S1) [41].

McCullers noted that treatment with NA inhibitors protects against secondary bacterial pneumonia, possibly because of medication-induced, reduced availability of viral NA [91]. It is intriguing to hypothesize that NA contributes to the growth of sialic acid-dependent pneumococci and alters complement resistance and $\mathrm{APC}$ regulation, including the binding of $\mathrm{CFH}$ on human tissue [24, 42]. Consequently, NA inhibitors may interfere with virus-induced complement dysregulation.

\section{Influenza TMA in kidney transplant recipients}

Kidney biopsies, where obtained during acute and post-acute iHUS reveal varied features $[25,33,37,38,92,93]$ that replicate key findings described in other forms of HUS [3], including endothelial cell swelling and luminal narrowing, focal mesangiolysis, intravascular deposition of fibrin, and diffuse granular staining for $\mathrm{C} 3$ [25, 33, 37, 92, 93], and in some cases, for $\operatorname{IgG}$ or $\operatorname{IgM}[25,37,92]$. No electron-dense deposits, virus-like particles or tubuloreticular inclusions were described [93]. The latter authors failed to demonstrate influenza A H3-specific hemagglutinin RNA using nested RT-PCR in the renal tissue [93].

\section{Laboratory diagnosis in patients with suspected iHUS}

All patients with HUS associated with seasonal or epidemic influenza should undergo rapid testing for ADAMTS13 activity, plasma $\mathrm{C} 3$, global hemolytic capacity (CH50 and $\mathrm{AH} 50$ ), circulating MAC (sC5b-9) and anti-CFH antibodies, in addition to genetic studies targeting HUS-associated complement and coagulation factors (Fig. 3). The detection in plasma of fibrin/fibrinogen degradation products (FDP; d-dimers), but not overt disseminated intravascular coagulation is common and does not preclude the diagnosis of HUS (Table 2) [29, 32, 


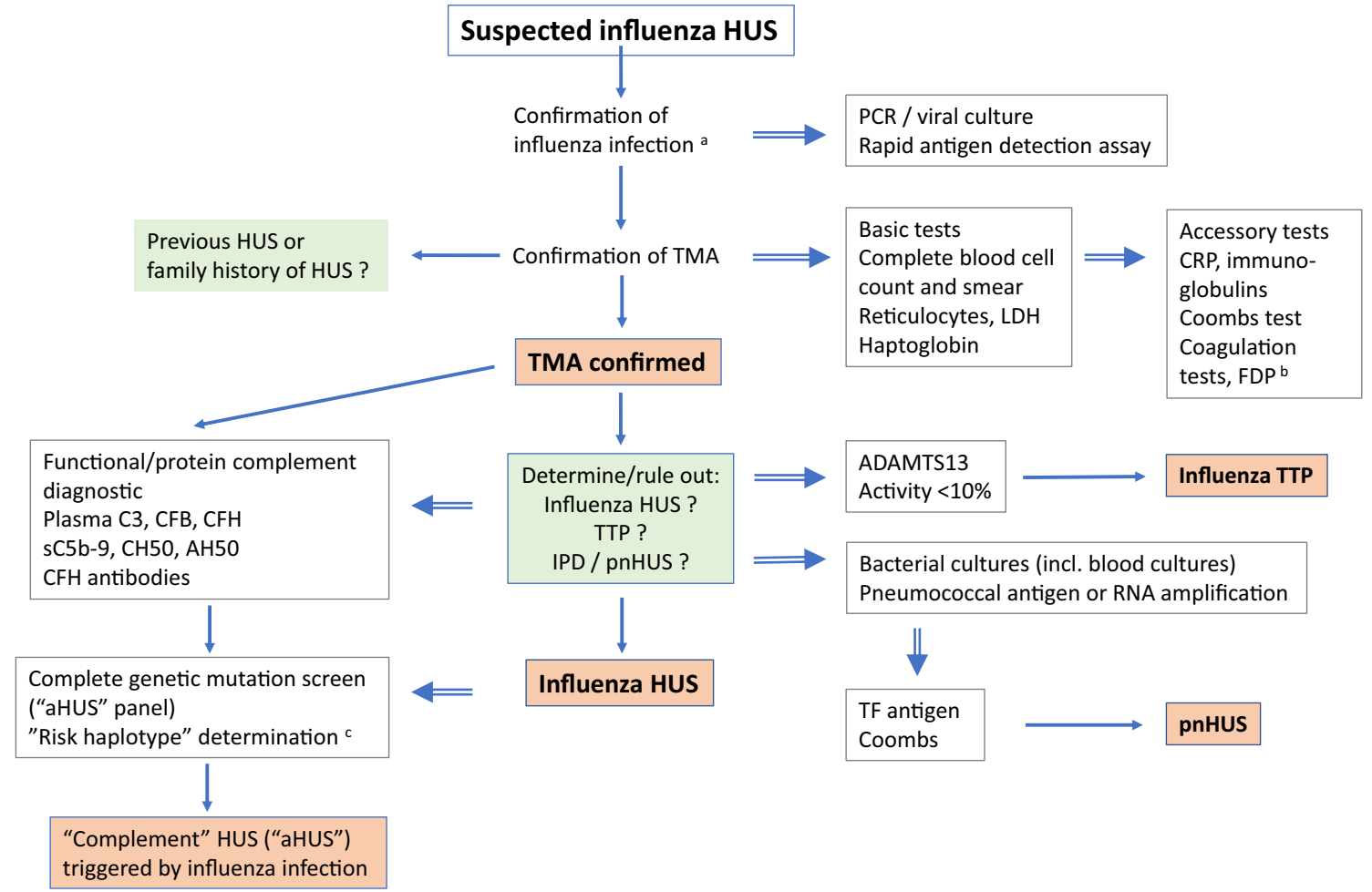

Fig. 3 Diagnostic algorithm for influenza HUS and related thrombotic microangiopathies. $a$ Influenza (or parainfluenza) virus; $b$ the detection in plasma of fibrin/fibrinogen degradation products (such as d-dimers), but full-blown disseminated intravascular coagulation is not common and does not preclude the diagnosis of HUS; $c$ combined complement regulator or coagulation protein mutations (e.g., membrane cofactor protein [MCP] and complement factor $\mathrm{H}(\mathrm{CFH})$ or single nucleotide

36, 38, 39]. Blood samples for complement protein and functional measurements must be taken before initiation of plasma or anti-complement therapy [94]. TTP is suspected in patients with MAHA with very low platelet counts and mild renal injury [5]. Interestingly, the 2 patients in this survey with bona fide TTP had a substantial rise in serum creatinine and one of them was dialyzed (Table 3). The presence of complicating pneumococcal pneumonia or sepsis should be ruled out in any case of (suspected) iHUS using blood cultures, direct Coombs test, coagulation studies, rapid antigen detection or nucleic acid-based assays, and evidence for NA activity (Fig. 3) [78, 84].

\section{Therapeutic management, outcome and prevention}

Patients with influenza-associated TMA benefit from best supportive care, similar to other forms of HUS [3, 84]. The outcome of iHUS is generally favorable; in our analysis, 3 out of 22 patients died (14\%; \#3, 4, and 9; all before 2008). Death was attributed to cardio-respiratory failure and/or CNS complications. All but one survivor recovered renal function after a median of 3 weeks (range 11-62 days; Table 2). In one of the polymorphisms (SNPs) in promoter regions [71]. aHUS atypical HUS, $C F B$ complement factor B, CRP C-reactive protein, FDP fibrin/ fibrinogen degradation products, IPD invasive pneumococcal disease, $L D H$ lactate dehydrogenase, $p n H U S$ pneumococcal/neuraminidase HUS, $P C R$ polymer chain reaction, TF antigen Thomsen-Friedenreich antigen (Gal $\beta 1-3 \mathrm{GalNAc} \alpha 1)$, TMA thrombotic microangiopathy, TTP thrombotic thrombocytopenic purpura

kidney transplant recipients, active TMA only ceased after graft nephrectomy. Interestingly, the patient was successfully retransplanted without preventive measures (\#1) [37]. There were no fatal outcomes or development of CKD during the A(H1N1) pandemic and the recent era (Table S1).

In comparison, STEC HUS is associated with mortality rates in children of $<4 \%$ during the acute illness, irrespective of the infecting STEC serotype [78, 95], and about 20\% develop generally minor, long-term renal dysfunction $[78,96]$. Mortality rates of pnHUS vary between 2 and $12 \%$ (up to $37 \%$ in those with pneumococcal meningitis) [78, 86, 97, 98], and are comparable with those found in the current iHUS survey. Analyses of S. pneumoniae- and influenza-associated HUS series are confounded by small numbers and an unknown proportion of patients with complement regulator defects $[22,87]$.

The efficacy, tolerability, and safety of NA inhibitors for the prevention and management of influenza infections have been demonstrated in large clinical trials that also included infants [99]. Flu vaccination reduces the incidence of pneumococcal HUS [78]. Oseltamivir also improved the outcome of secondary pneumonia, and subsequent treatment with an antibiotic led to $100 \%$ survival in a murine influenza infection 


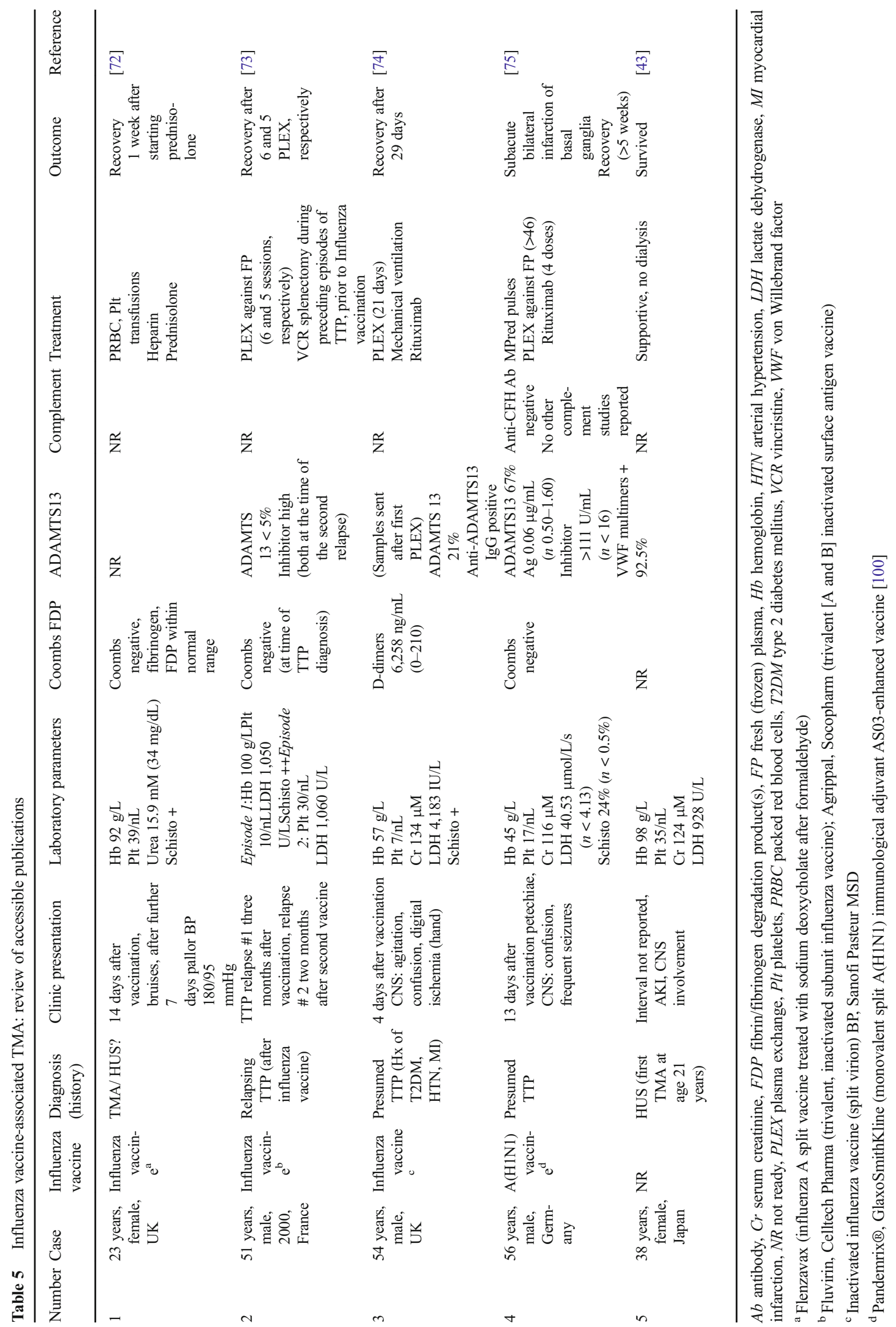


model [91]. However, there is no experimental model of iHUS or iHUS/TTP prevention, and current evidence is lacking as to whether NA inhibitors prevent or ameliorate influenza TMA. In our analysis, $71 \%$ of treated and reported patients received the NA inhibitor only after the diagnosis of HUS had been made (Table 2).

Individual and population immunity against endemic or epidemic influenza strains is expected to reduce the occurrence of iTMA. However, the immunization history is rarely mentioned in the available case reports. Furthermore, the notorious variability of the predicted antigen changes hampers the efficacy of influenza A vaccines [17]. Although vaccination has been linked to HUS or TTP in a few instances (Table 5), data are scarce and should not be construed as an argument against active immunization. In contrast to natural infections, vaccination allows monitoring for signs of postvaccination TMA and prompt intervention in persons with a history of (atypical) HUS.

\section{Is there a role for plasma infusion, PLEX or anti-complement agents in iHUS?}

Our survey covers a period of 46 years representing different eras, seasonal and epidemic influenza strains (Table 1), and therapeutic approaches (Tables 2, S1). Overall, 16 out of 24 patients with available data received any plasma therapy (67\%): 5 were treated with plasma infusions and 12 were treated with PLEX (1 patient received both modalities; Table 2). Two patients were given eculizumab: patient \#16, carrier of a $\mathrm{C} 3$ gain-of-function mutation, who had lost two previous renal allografts owing to recurrent HUS [33], received eculizumab when HUS recurred in the third allograft during the $\mathrm{A}(\mathrm{H} 1 \mathrm{~N} 1)$ influenza pandemic. Patient \#25 was a 6month-old infant with influenza B-associated HUS who received eculizumab when he relapsed while recovering from his first episode of aHUS. He was later shown to have a heterozygous MCP mutation (Table 4) [23].

Treatment of iHUS hinges on the direct effects of the influenza infection, complicating bacterial pneumonia, "best" supportive care, including dialysis and blood products, if needed, and plasma or anti-complement therapy (e.g., eculizumab), particularly in the presence of complement regulator deficiencies (Table 6). Recommendations for "atypical" HUS, including anti-complement agents or PLEX, should be implemented in patients with iHUS who present functional or genetic evidence for complement dysregulation or have a previous history of (atypical) HUS, a positive family history of (a)HUS, or HUS recurrence after kidney transplantation (Table 6). In the case of profound ADAMTS13 depletion and suspected TTP, most authors recommend PLEX and immunosuppressive therapy $[2,84,94]$.

Table 6 Treatment of influenza-associated TMA

\begin{tabular}{|c|c|c|}
\hline Treatment & Details & Comments/references \\
\hline \multirow[t]{5}{*}{ Best supportive care } & Respiratory support & \\
\hline & Intravascular volume status & \\
\hline & Blood pressure control & \\
\hline & Blood products ( $\mathrm{PRBC}$, platelet transfusion) & \\
\hline & Diuretics & Only after sufficient intravascular volume \\
\hline Renal replacement therapy & HD, PD, CRRT & $\begin{array}{l}\text { Based on tolerability, circulatory, and cardiac stability } \\
\text { Expertise and equipment availability }\end{array}$ \\
\hline \multirow[t]{2}{*}{ Antimicrobial therapy } & NA inhibitors (e.g., oseltamivir) & $\begin{array}{l}\text { Potential to prevent HUS if given early during infection (or at } \\
\text { exposure?) [97]. Preventive efficacy remains to be } \\
\text { proven }\end{array}$ \\
\hline & $\begin{array}{l}\text { Antibiotics (3rd generation cephalosporins } \\
\text { and others) }\end{array}$ & $\begin{array}{l}\text { Antibiotics reduce rates of complicating bacterial } \\
\text { pneumonia and possibly pnHUS }[79,89]\end{array}$ \\
\hline \multirow[t]{2}{*}{$\begin{array}{l}\text { Plasma and anti-complement } \\
\text { therapy }\end{array}$} & $\begin{array}{l}\text { Plasma exchange (PLEX) } \\
\text { (Plasma infusion, PI) }\end{array}$ & $\begin{array}{l}\text { Option for patients with complement dysregulation } \\
\text { and/or evidence of autoimmune TMA/TTP } \\
\text { (anti-CFH or anti-ADAMTS13) } \\
\text { PI restricted to unavailability of PLEX } \\
\text { Note: spontaneous recovery of iHUS may occur } \\
\text { (see Tables } 2 \text { and S1) }\end{array}$ \\
\hline & Anti-complement antibody & $\begin{array}{l}\text { Treatment of choice for children with iHUS and } \\
\text { suspected or proven complement dysregulation } \\
\text { (pathogenic mutation, relapsing/recurrent HUS) } \\
{[23,33]}\end{array}$ \\
\hline
\end{tabular}

CRRT continuous renal replacement therapy, $H D$ hemodialysis, $N A$ neuraminidase, $P D$ peritoneal dialysis, $p n H U S$ pneumococcal/neuraminidaseassociated HUS, PRBC packed red blood cells, TMA thrombotic microangiopathy, TTP thrombotic thrombocytopenia 


\section{Conclusions and future areas of research}

Influenza-associated HUS or TMA is rare. It has been linked to influenza A and influenza B infections and, in several instances, pathogenic complement gene mutations. The outcome is generally favorable, but depends on underlying complement gene deficiencies and/or the presence of CFH or ADAMTS13 autoantibodies. Identification of the etiology and differentiation between HUS due to complement dysregulation, where the Influenza virus may act as a potent trigger, and influenza-associated HUS without identifiable complement abnormalities, are critical for acute and long-term management.

The term "atypical" HUS has been originally coined to describe a heterogeneous group of infrequent forms of HUS not associated with STEC colitis. The current, interchangeable use of the epithet "atypical" that may or may not include HUS owing to pneumococcal infection and various metabolic and other conditions, including "secondary" forms of HUS $[1,7]$ and HUS strictly caused by complement dysregulation ("primary complement-mediated HUS" or "HUS with dysregulation of the APC" [2]), leads to confusion about the etiology of and appropriate therapy for different forms of HUS. We argue in favor of etiologically defined designations that correspond to different pathomechanisms and lead to rational, mechanism-targeting therapies [2, 3, 94].

As detailed in this review, the pathogenesis of influenza virus-induced TMA is varied. It is intriguing to hypothesize that influenza-derived NA plays a causative role. Membrane glycan desialylation by functionally active, virus membranebound NA may cause transient loss of resistance to APC activation on epithelial and/or vascular endothelial cells. Alternatively, virus-specific, alternative mechanisms of (microvascular) endothelial injury resulting in an HUS phenotype need be explored. Both warrant further studies.

The diagnostic workup in most of the reviewed cases is incomplete from today's perspective. Some influenza strains appear to be potent alternative pathway activators in vivo [68] and therefore trigger HUS in non-immune individuals, uncovering specific regulator haplo-insufficiency or changes in noncoding complement gene sequences [71]. Although the number of genetically studied iHUS cases is small, it is noticeable that all identified patients carried mutations in the MCP or C3 gene, occasionally combined with other mutations. Further delineation of "risk haplotypes" and specific microbial agents or their products could have therapeutic and preventive implications and will advance our understanding of this intriguing disease group.

At present, general treatment recommendations for iHUS and iTTP are lacking. In view of the high proportion of patients with APC dysregulation, PLEX or anti-complement agents constitute a reasonable therapeutic approach, while striving for a rapid and comprehensive etiological diagnosis.
Acknowledgements The authors thank Dr Dorothy Moore, Division of Infectious Diseases, The Montreal Children's Hospital, McGill University Health Centre, for carefully reading the manuscript.

Funding None.

\section{Compliance with ethical standards}

Conflicts of interest M. Bitzan served on Advisory Boards for Alexion Pharmaceuticals. The authors declare no other interests.

Open Access This article is distributed under the terms of the Creative Commons Attribution 4.0 International License (http:// creativecommons.org/licenses/by/4.0/), which permits unrestricted use, distribution, and reproduction in any medium, provided you give appropriate credit to the original author(s) and the source, provide a link to the Creative Commons license, and indicate if changes were made.

\section{References}

1. Riedl M, Fakhouri F, Le Quintrec M, Noone DG, Jungraithmayr TC, Fremeaux-Bacchi V, Licht C (2014) Spectrum of complement-mediated thrombotic microangiopathies: pathogenetic insights identifying novel treatment approaches. Semin Thromb Hemost 40:444-464

2. Fakhouri F, Zuber J, Fremeaux-Bacchi V, Loirat C (2017) Haemolytic uraemic syndrome. Lancet 390:681-696

3. Bitzan M, Lapeyraque AL (2016) Postinfectious hemolytic uremic syndrome. In: Geary D, Schaefer F (eds) Pediatric kidney disease. Springer, Berlin, pp 653-731

4. Kaushansky K (2016) Blood's 70th anniversary: the elusive von Willebrand factor-cleaving protease. Blood 127:2163-2164

5. Tsai HM (2013) Thrombotic thrombocytopenic purpura and the atypical hemolytic uremic syndrome: an update. Hematol Oncol Clin North Am 27:565-584

6. Ferrari S, Mudde GC, Rieger M, Veyradier A, Kremer Hovinga JA, Scheiflinger F (2009) IgG subclass distribution of antiADAMTS13 antibodies in patients with acquired thrombotic thrombocytopenic purpura. J Thromb Haemost 7:1703-1710

7. Shatzel JJ, Taylor JA (2017) Syndromes of thrombotic microangiopathy. Med Clin North Am 101:395-415

8. Vieira-Martins P, El Sissy C, Bordereau P, Gruber A, Rosain J, Fremeaux-Bacchi V (2016) Defining the genetics of thrombotic microangiopathies. Transfus Apher Sci 54:212-219

9. Delvaeye M, Noris M, De Vriese A, Esmon CT, Esmon NL, Ferrell G, Del-Favero J, Plaisance S, Claes B, Lambrechts D, Zoja C, Remuzzi G, Conway EM (2009) Thrombomodulin mutations in atypical hemolytic-uremic syndrome. N Engl J Med 361: 345-357

10. Epand RM, So V, Jennings W, Khadka B, Gupta RS, Lemaire M (2016) Diacylglycerol kinase-epsilon: properties and biological roles. Front Cell Dev Biol 4:112

11. Bu F, Maga T, Meyer NC, Wang K, Thomas CP, Nester CM, Smith RJ (2014) Comprehensive genetic analysis of complement and coagulation genes in atypical hemolytic uremic syndrome. $\mathrm{J}$ Am Soc Nephrol 25:55-64

12. Jokiranta TS (2017) HUS and atypical HUS. Blood 129:28472856

13. Beck BB, van Spronsen F, Diepstra A, Berger RM, Komhoff M (2017) Renal thrombotic microangiopathy in patients with cblC defect: review of an under-recognized entity. Pediatr Nephrol 32: 733-741 
14. Johnson NP, Mueller J (2002) Updating the accounts: global mortality of the 1918-1920 "Spanish" influenza pandemic. Bull Hist Med 76:105-115

15. Dawood FS, Iuliano AD, Reed C, Meltzer MI, Shay DK, Cheng PY, Bandaranayake D, Breiman RF, Brooks WA, Buchy P, Feikin DR, Fowler KB, Gordon A, Hien NT, Horby P, Huang QS, Katz MA, Krishnan A, Lal R, Montgomery JM, Molbak K, Pebody R, Presanis AM, Razuri H, Steens A, Tinoco YO, Wallinga J, Yu H, Vong S, Bresee J, Widdowson MA (2012) Estimated global mortality associated with the first 12 months of 2009 pandemic influenza A H1N1 virus circulation: a modelling study. Lancet Infect Dis 12:687-695

16. Center for Disease Control and Prevention (2010) Estimates of deaths associated with seasonal influenza-United States, 19762007. MMWR Morb Mortal Wkly Rep 59:1057-1062

17. Paules C, Subbarao K (2017) Influenza. Lancet 390:697-708

18. Air GM (2012) Influenza neuraminidase. Influenza Other Respir Viruses 6:245-256

19. Stray SJ, Cummings RD, Air GM (2000) Influenza virus infection of desialylated cells. Glycobiology 10:649-658

20. Garcia CC, Weston-Davies W, Russo RC, Tavares LP, Rachid MA, Alves-Filho JC, Machado AV, Ryffel B, Nunn MA, Teixeira MM (2013) Complement C5 activation during influenza A infection in mice contributes to neutrophil recruitment and lung injury. PLoS One 8:e64443

21. Yang J, Liu S, Du L, Jiang S (2016) A new role of neuraminidase (NA) in the influenza virus life cycle: implication for developing NA inhibitors with novel mechanism of action. Rev Med Virol 26: 242-250

22. Van Hoeve K, Vandermeulen C, Van Ranst M, Levtchenko E, van den Heuvel L, Mekahli D (2017) Occurrence of atypical HUS associated with influenza B. Eur J Pediatr 176:449-454

23. Kobbe R, Schild R, Christner M, Oh J, Loos S, Kemper MJ (2017) Case report - atypical hemolytic uremic syndrome triggered by influenza B. BMC Nephrol 18:96

24. Gilbert RD, Nagra A, Haq MR (2013) Does dysregulated complement activation contribute to haemolytic uraemic syndrome secondary to Streptococcus pneumoniae? Med Hypotheses 81:400 403

25. Wasserstein A, Hill G, Goldfarb S, Goldberg M (1981) Recurrent thrombotic thrombocytopenic purpura after viral infection. Clinical and histologic simulation of chronic glomerulonephritis. Arch Intern Med 141:685-687

26. Bento D, Mapril J, Rocha C, Marchbank KJ, Kavanagh D, Barge D, Strain L, Goodship TH, Meneses-Oliveira C (2010) Triggering of atypical hemolytic uremic syndrome by influenza A (H1N1). Ren Fail 32:753-756

27. Farinha A, Carrilho P, Felgueiras J, Natario A, Assuncao J, Vinhas J (2010) Haemolytic uraemic syndrome associated with H1N1 influenza. NDT Plus 3:447-448

28. Printza N, Roilides E, Kotsiou M, Zafeiriou D, Hatzidimitriou V, Papachristou F (2011) Pandemic influenza A (H1N1) 2009associated hemolytic uremic syndrome. Pediatr Nephrol 26:143144

29. Trachtman H, Sethna C, Epstein R, D'Souza M, Rubin LG, Ginocchio CC (2011) Atypical hemolytic uremic syndrome associated with H1N1 influenza A virus infection. Pediatr Nephrol 26: 145-146

30. Çaltik A, Akyüz SG, Erdogan Ö, Demircin G (2011) Hemolytic uremic syndrome triggered with a new pandemic virus: influenza A (H1N1). Pediatr Nephrol 26:147-148

31. Rhee H, Song SH, Lee YJ, Choi HJ, Ahn JH, Seong EY, Lee SB, Kwak IS (2011) Pandemic H1N1 influenza A viral infection complicated by atypical hemolytic uremic syndrome and diffuse alveolar hemorrhage. Clin Exp Nephrol 15:948-952
32. Golubovic E, Miljkovic P, Zivic S, Jovancic D, Kostic G (2011) Hemolytic uremic syndrome associated with novel influenza A H1N1 infection. Pediatr Nephrol 26:149-150

33. Al-Akash SI, Almond PS, Savell VH Jr, Gharaybeh SI, Hogue C (2011) Eculizumab induces long-term remission in recurrent posttransplant HUS associated with $\mathrm{C} 3$ gene mutation. Pediatr Nephrol 26:613-619

34. Mammas IN, Koutsaftiki C, Papantzimas K, Symeonoglou Z, Koussouri M, Theodoridou M, Myriokefalitakis N (2011) Thrombocytic thrombocytopenic purpura in a child with A/ H1N1 influenza infection. J Clin Virol 51:146-147

35. Koh YR, Hwang SH, Chang CL, Lee EY, Son HC, Kim HH (2012) Thrombotic thrombocytopenic purpura triggered by influenza A virus subtype H1N1 infection. Transfus Apher Sci 46:2528

36. Tsujii N, Nogami K, Yoshizawa H, Hayakawa M, Isonishi A, Matsumoto M, Shima M (2016) Influenza-associated thrombotic microangiopathy with unbalanced von Willebrand factor and a disintegrin and metalloproteinase with a thrombospondin type 1 motif, member 13 levels in a heterozygous protein S-deficient boy. Pediatr Int 58:926-929

37. Petersen VP, Olsen TS (1971) Late renal transplant failure due to the hemolytic-uremic syndrome. Acta Med Scand 189:377-380

38. Davison AM, Thomson D, Robson JS (1973) Intravascular coagulation complicating influenza A virus infection. Br Med J 1:654-655

39. Kosugi N, Tsurutani Y, Isonishi A, Hori Y, Matsumoto M, Fujimura Y (2010) Influenza A infection triggers thrombotic thrombocytopenic purpura by producing the anti-ADAMTS13 IgG inhibitor. Intern Med 49:689-693

40. Joseph A, Fangio P, Barbier C, Hayon J, Loubières Y, Pichereau C, Outin H, Alves M (2016) Seasonal flu as a triggering factor for acquired thrombotic thrombocytopenic purpura. J Hematol Thromboembolic Dis. https://doi.org/10.4172/2329-8790. 1000243

41. Lei TH, Hsia SH, Wu CT, Lin JJ (2010) Streptococcus pneumoniae-associated haemolytic uremic syndrome following influenza A virus infection. Eur J Pediatr 169:237-239

42. Varki A, Gagneux P (2012) Multifarious roles of sialic acids in immunity. Ann N Y Acad Sci 1253:16-36

43. Matsumoto T, Fan X, Ishikawa E, Ito M, Amano K, Toyoda H, Komada Y, Ohishi K, Katayama N, Yoshida Y, Matsumoto M, Fujimura Y, Ikejiri M, Wada H, Miyata T (2014) Analysis of patients with atypical hemolytic uremic syndrome treated at the Mie University Hospital: concentration of C3 p.I1157T mutation. Int J Hematol 100:437-442

44. Amato-Gauci A, Zucs P, Snacken R, Ciancio B, Lopez V, Broberg E, Penttinen P, Nicoll A, European Influenza Surveillance Network EISN (2011) Surveillance trends of the 2009 influenza A(H1N1) pandemic in Europe. Euro Surveill 16(26):pii=19903

45. Allen U, Licht C (2011) Pandemic H1N1 influenza A infection and (atypical) HUS-more than just another trigger? Pediatr Nephrol 26:3-5

46. Girard MP, Tam JS, Assossou OM, Kieny MP (2010) The 2009 A (H1N1) influenza virus pandemic: a review. Vaccine 28:48954902

47. Fischer WA 2nd, Gong M, Bhagwanjee S, Sevransky J (2014) Global burden of influenza as a cause of cardiopulmonary morbidity and mortality. Glob Heart 9:325-336

48. Sobolev O, Binda E, O'Farrell S, Lorenc A, Pradines J, Huang Y, Duffner J, Schulz R, Cason J, Zambon M, Malim MH, Peakman M, Cope A, Capila I, Kaundinya GV, Hayday AC (2016) Adjuvanted influenza-H1N1 vaccination reveals lymphoid signatures of age-dependent early responses and of clinical adverse events. Nat Immunol 17:204-213

49. Sanderson NS, Zimmermann M, Eilinger L, Gubser C, SchaerenWiemers N, Lindberg RL, Dougan SK, Ploegh HL, Kappos L, 
Derfuss T (2017) Cocapture of cognate and bystander antigens can activate autoreactive B cells. Proc Natl Acad Sci U S A 114:734 739

50. Xu G, Kiefel MJ, Wilson JC, Andrew PW, Oggioni MR, Taylor GL (2011) Three Streptococcus pneumoniae sialidases: three different products. J Am Chem Soc 133:1718-1721

51. Shieh WJ, Blau DM, Denison AM, Deleon-Carnes M, Adem P, Bhatnagar J, Sumner J, Liu L, Patel M, Batten B, Greer P, Jones T, Smith C, Bartlett J, Montague J, White E, Rollin D, Gao R, Seales C, Jost H, Metcalfe M, Goldsmith CS, Humphrey C, Schmitz A, Drew C, Paddock C, Uyeki TM, Zaki SR (2010) 2009 pandemic influenza A (H1N1): pathology and pathogenesis of 100 fatal cases in the United States. Am J Pathol 177:166-175

52. Chan MC, Chan RW, Yu WC, Ho CC, Chui WH, Lo CK, Yuen KM, Guan YI, Nicholls JM, Peiris JS (2009) Influenza H5N1 virus infection of polarized human alveolar epithelial cells and lung microvascular endothelial cells. Respir Res 10:102

53. Armstrong SM, Wang C, Tigdi J, Si X, Dumpit C, Charles S, Gamage A, Moraes TJ, Lee WL (2012) Influenza infects lung microvascular endothelium leading to microvascular leak: role of apoptosis and claudin-5. PLoS One 7:e47323

54. Bombeli T, Schwartz BR, Harlan JM (1999) Endothelial cells undergoing apoptosis become proadhesive for nonactivated platelets. Blood 93:3831-3838

55. Armstrong SM, Darwish I, Lee WL (2013) Endothelial activation and dysfunction in the pathogenesis of influenza A virus infection. Virulence 4:537-542

56. Terada H, Baldini M, Ebbe S, Madoff MA (1966) Interaction of influenza virus with blood platelets. Blood 28:213-228

57. Rondina MT, Brewster B, Grissom CK, Zimmerman GA, Kastendieck DH, Harris ES, Weyrich AS (2012) In vivo platelet activation in critically ill patients with primary 2009 influenza A(H1N1). Chest 141:1490-1495

58. Boilard E, Pare G, Rousseau M, Cloutier N, Dubuc I, Levesque T, Borgeat P, Flamand L (2014) Influenza virus H1N1 activates platelets through FcgammaRIIA signaling and thrombin generation. Blood 123:2854-2863

59. O'Brien KB, Morrison TE, Dundore DY, Heise MT, SchultzCherry S (2011) A protective role for complement $\mathrm{C} 3$ protein during pandemic $2009 \mathrm{H} 1 \mathrm{~N} 1$ and H5N1 influenza A virus infection. PLoS One 6:e17377

60. Ekdahl KN, Teramura Y, Hamad OA, Asif S, Duehrkop C, Fromell K, Gustafson E, Hong J, Kozarcanin H, Magnusson PU, Huber-Lang M, Garred P, Nilsson B (2016) Dangerous liaisons: complement, coagulation, and kallikrein/kinin cross-talk act as a linchpin in the events leading to thromboinflammation. Immunol Rev 274:245-269

61. Freeley S, Kemper C, Le Friec G (2016) The "ins and outs" of complement-driven immune responses. Immunol Rev 274:16-32

62. Ricklin D, Hajishengallis G, Yang K, Lambris JD (2010) Complement: a key system for immune surveillance and homeostasis. Nat Immunol 11:785-797

63. Wang R, Xiao H, Guo R, Li Y, Shen B (2015) The role of C5a in acute lung injury induced by highly pathogenic viral infections. Emerg Microbes Infect 4:e28

64. Tripathi S, White MR, Hartshorn KL (2015) The amazing innate immune response to influenza A virus infection. Innate Immun 21: 73-98

65. Jayasekera JP, Moseman EA, Carroll MC (2007) Natural antibody and complement mediate neutralization of influenza virus in the absence of prior immunity. J Virol 81:3487-3494

66. Bjornson AB, Mellencamp MA, Schiff GM (1991) Complement is activated in the upper respiratory tract during influenza virus infection. Am Rev Respir Dis 143:1062-1066

67. Ohta R, Torii Y, Imai M, Kimura H, Okada N, Ito Y (2011) Serum concentrations of complement anaphylatoxins and proinflammatory mediators in patients with $2009 \mathrm{H} 1 \mathrm{~N} 1$ influenza. Microbiol Immunol 55:191-198

68. Berdal JE, Mollnes TE, Waehre T, Olstad OK, Halvorsen B, Ueland T, Laake JH, Furuseth MT, Maagaard A, Kjekshus H, Aukrust P, Jonassen CM (2011) Excessive innate immune response and mutant D222G/N in severe A (H1N1) pandemic influenza. J Infect 63:308-316

69. Sun S, Zhao G, Liu C, Wu X, Guo Y, Yu H, Song H, Du L, Jiang S, Guo R, Tomlinson S, Zhou Y (2013) Inhibition of complement activation alleviates acute lung injury induced by highly pathogenic avian influenza H5N1 virus infection. Am J Respir Cell Mol Biol 49:221-230

70. Kopf M, Abel B, Gallimore A, Carroll M, Bachmann MF (2002) Complement component $\mathrm{C} 3$ promotes $\mathrm{T}$-cell priming and lung migration to control acute influenza virus infection. Nat Med 8: 373-378

71. De Cordoba SR, Hidalgo MS, Pinto S, Tortajada A (2014) Genetics of atypical hemolytic uremic syndrome (aHUS). Semin Thromb Hemost 40:422-430

72. Brown RC, Blecher TE, French EA, Toghill PJ (1973) Thrombotic thrombocytopenic purpura after influenza vaccination. Br Med J 2:303

73. Brodin-Sartorius A, Guebre-Egziabher F, Fouque D, Cozon G, Villar E, Laville M, Juillard L (2006) Recurrent idiopathic thrombotic thrombocytopenic purpura: a role for vaccination in disease relapse? Am J Kidney Dis 48:e31-e34

74. Dias PJ, Gopal S (2009) Refractory thrombotic thrombocytopenic purpura following influenza vaccination. Anaesthesia 64:444-446

75. Hermann R, Pfeil A, Busch M, Kettner C, Kretzschmar D, Hansch A, La Rosee P, Wolf G (2010) Very severe thrombotic thrombocytopenic purpura (TTP) after H1N1 vaccination. Med Klin (Munich) 105:663-668

76. Gilley RP, Orihuela CJ (2014) Pneumococci in biofilms are noninvasive: implications on nasopharyngeal colonization. Front Cell Infect Microbiol 4:163

77. Copelovitch L, Kaplan BS (2008) Streptococcus pneumoniaeassociated hemolytic uremic syndrome. Pediatr Nephrol 23: 1951-1956

78. Spinale JM, Ruebner RL, Kaplan BS, Copelovitch L (2013) Update on Streptococcus pneumoniae associated hemolytic uremic syndrome. Curr Opin Pediatr 25:203-208

79. McCullers JA (2006) Insights into the interaction between influenza virus and pneumococcus. Clin Microbiol Rev 19:571-582

80. Manco S, Hernon F, Yesilkaya H, Paton JC, Andrew PW, Kadioglu A (2006) Pneumococcal neuraminidases A and B both have essential roles during infection of the respiratory tract and sepsis. Infect Immun 74:4014-4020

81. Gut H, Xu G, Taylor GL, Walsh MA (2011) Structural basis for Streptococcus pneumoniae NanA inhibition by influenza antivirals zanamivir and oseltamivir carboxylate. J Mol Biol 409:496503

82. Walther E, Xu Z, Richter M, Kirchmair J, Grienke U, Rollinger JM, Krumbholz A, Saluz HP, Pfister W, Sauerbrei A, Schmidtke M (2016) Dual acting neuraminidase inhibitors open new opportunities to disrupt the lethal synergism between Streptococcus pneumoniae and influenza virus. Front Microbiol 7:357

83. Palacios G, Hornig M, Cisterna D, Savji N, Bussetti AV, Kapoor V, Hui J, Tokarz R, Briese T, Baumeister E, Lipkin WI (2009) Streptococcus pneumoniae coinfection is correlated with the severity of H1N1 pandemic influenza. PLoS One 4:e8540

84. Loirat C, Saland J, Bitzan M (2012) Management of hemolytic uremic syndrome. Presse Med 41:e115-e135

85. Fischer K, Poschmann A, Oster H (1971) Severe pneumonia with hemolysis caused by neuraminidase. Detection of cryptantigens by indirect immunofluorescent technic. Monatsschr Kinderheilkd 119:2-8 
86. Constantinescu AR, Bitzan M, Weiss LS, Christen E, Kaplan BS, Cnaan A, Trachtman H (2004) Non-enteropathic hemolytic uremic syndrome: causes and short-term course. Am J Kidney Dis 43:976-982

87. Szilágyi A, Kiss N, Bereczki C, Talosi G, Racz K, Turi S, Gyorke Z, Simon E, Horvath E, Kelen K, Reusz GS, Szabo AJ, Tulassay T, Prohaszka Z (2013) The role of complement in Streptococcus pneumoniae-associated haemolytic uraemic syndrome. Nephrol Dial Transplant 28:2237-2245

88. Lambre CR, Kazatchkine MD, Maillet F, Thibon M (1982) Guinea pig erythrocytes, after their contact with influenza virus, acquire the ability to activate the human alternative complement pathway through virus-induced desialation of the cells. J Immunol 128:629-634

89. McCullers JA (2014) The public health policy implications of understanding metabiosis. Cell Host Microbe 16:3-4

90. Grijalva CG, Griffin MR, Edwards KM, Williams JV, Gil AI, Verastegui H, Hartinger SM, Vidal JE, Klugman KP, Lanata CF (2014) The role of influenza and parainfluenza infections in nasopharyngeal pneumococcal acquisition among young children. Clin Infect Dis 58:1369-1376

91. McCullers JA (2004) Effect of antiviral treatment on the outcome of secondary bacterial pneumonia after influenza. J Infect Dis 190: $519-526$

92. Asaka M, Ishikawa I, Nakazawa T, Tomosugi N, Yuri T, Suzuki K (2000) Hemolytic uremic syndrome associated with influenza A virus infection in an adult renal allograft recipient: case report and review of the literature. Nephron 84:258-266

93. Watanabe T (2001) Hemolytic uremic syndrome associated with influenza A virus infection. Nephron 89:359-360

94. Loirat C, Fakhouri F, Ariceta G, Besbas N, Bitzan M, Bjerre A, Coppo R, Emma F, Johnson S, Karpman D, Landau D, Langman CB, Lapeyraque AL, Licht C, Nester C, Pecoraro C, Riedl M, van de Kar NC, Van de Walle J, Vivarelli M, Fremeaux-Bacchi V, HUS International (2016) An international consensus approach to the management of atypical hemolytic uremic syndrome in children. Pediatr Nephrol 31:15-39

95. Loos S, Aulbert W, Hoppe B, Ahlenstiel-Grunow T, Kranz B, Wahl C, Staude H, Humberg A, Benz K, Krause M, Pohl M, Liebau MC, Schild R, Lemke J, Beringer O, Muller D, Hartel C, Wigger M, Vester U, Konrad M, Haffner D, Pape L, Oh J, Kemper MJ (2017) Intermediate follow-up of pediatric patients with hemolytic uremic syndrome during the 2011 outbreak caused by E. coli O104:H4. Clin Infect Dis 64:1637-1643

96. Rosales A, Hofer J, Zimmerhackl LB, Jungraithmayr TC, Riedl M, Giner T, Strasak A, Orth-Holler D, Wurzner R, Karch H, German-Austrian HUS Study Group (2012) Need for long-term follow-up in enterohemorrhagic Escherichia coli-associated hemolytic uremic syndrome due to late-emerging sequelae. Clin Infect Dis 54:1413-1421

97. Waters AM, Kerecuk L, Luk D, Haq MR, Fitzpatrick MM, Gilbert $\mathrm{RD}$, Inward C, Jones C, Pichon B, Reid C, Slack MP, Van't Hoff W, Dillon MJ, Taylor CM, Tullus K (2007) Hemolytic uremic syndrome associated with invasive pneumococcal disease: the United Kingdom experience. J Pediatr 151:140-144

98. Prestidge C, Wong W (2009) Ten years of pneumococcalassociated haemolytic uraemic syndrome in New Zealand children. J Paediatr Child Health 45:731-735

99. Rath BA, Blumentals WA, Miller MK, Starzyk K, Tetiurka B, Wollenhaupt M (2015) A prospective observational study of oseltamivir safety and tolerability in infants and young children $\leq 24$ months. Pharmacoepidemiol Drug Saf 24:286-296

100. Mayet A, Duron S, Nivoix P, Haus-Cheymol R, Ligier C, Gache K, Dia A, Manet G, Verret C, Pommier de Santi V, Bigaillon C, Martinaud C, Piarroux M, Faure N, Hupin C, Decam C, Chaudet H, Meynard JB, Nicand E, Deparis X, Migliani R (2011) Novel influenza $\mathrm{A}(\mathrm{H} 1 \mathrm{~N} 1)$ outbreak among French armed forces in 2009: results of Military Influenza Surveillance System. Public Health 125:494-500 